\title{
PERSEPSI KEPALA RUANGAN DAN PERAWAT PELAKSANA TENTANG PERMASALAHAN MANAJEMEN DALAM MENERAPKAN PENDOKUMENTASIAN PROSES KEPERAWATAN DI RUMAH SAKIT UMUM PUSAT NASIONAL DR. CIPTO MANGUNKUSUMO (RSCM) JAKARTA - 2001
}

Herawani Azies*, Elly Nurachmah**, S. Notoatmojo***

\begin{abstract}
Abstrak
Tujuan penelitian adalah untuk mengetahui secra mendalam persepsi kepala ruangan dan perawat pelaksana tentang permasalahan manajemen dalam menerapkan pendokumentasian proses keperawatan di RSCM. Desain penelitian kulitatif adalah deskriptif-eksploratif dengan menggunakan pendekatan fenomenologikal dan melibatkan 24 responden dari dua kelompok kepala ruangan dan perawat pelaksana, masing-masing terdiri dari empat orang dari setiap kelompok untuk wawancara mendalam, dan delapan orang dari tiap kelompok untuk kelompok diskusi terfokus. Hasil penelitian menunjukkann ada beberapa tema yang muncul dari setiap variable yang diteliti yaitu untuk variable pemahaman dokumentasi keperawatan diperoleh tema catatn, aspek legal, alat komunikasi dan informasi, serta dokumentasi sebagai penelitian. Pada variable fungsi manajeman, fungsi perencanaan diperoleh sumber belum optimal, fungsi pengorganisasian diperoleh uraian tugas belum jelas, fungsi pengarahan diperoleh tema pendelegasian, dan dari fungsi pengawasan diperoleh penampilan kinerja belum terlaksana secara berkesinambungan, standar praktik belum difungsikan secara optimal, pendidikan kepala ruangan belum selesai, dan tema spek psikososial. Rekomendasi ditujukan pada bebrapa pihak yang terlibat dalam pelayanan keperawatan di rumah sakit agar mendukung terwujudnya sistem pendokumentasian yang lebih baik. Penelitian lebih lanjut perlu dilakukan agar pendokumentasian keperawatan dapat leih dipertanggungjawabkan baik secara legal, social, maupun professional.
\end{abstract}

Kata kunci: persepsi, masalah manajemen keperawatan, fumgsi manajemen, pendokumentasian

\begin{abstract}
The purpose of the research was to identify the in-depth perception of the head as nursing managers and the clinical nurses on the management problems to implement nursing process documentation at RSCM. The design of the qualitative research was descriptive explorative using a phenomenological approach. Twenty-four respondents were participated in the study: consisted of two groups, which were the group of head nursing and the group of clinical nurses equally. These groups were divided into eight persons in the group for in depth interview and sixteen persons for focus group discussions. The result of the study showed several themes from each variable. The variable of understanding the nursing documentation had themes of documentation as notes, legal aspect, communication and information media, and as a material of research study. The variable of management function produced varies of themes such as resource planning has not been implemented optimally, job description is unclear, delegation of tasks, work performance has been monitored consistently, standard of practice has not been conveyed to several components of nursing service in the hospital to support a better nursing
\end{abstract}


documentation. A further research should be done to achieve more comprehensive findings lead to a nursing documentation that can be legally, social, and professionally accountable.

Key word: perception, problems in nursing management, management function, documentation 